\title{
Effect of carbenicillin, gentamicin, and their combination on experimental Pseudomonas aeruginosa urinary tract infection
}

\author{
L. KONÍČKOVÁ AND V. PRÁT
}

\begin{abstract}
From the Research Institute for Pharmacy and Biochemistry, Institute for Cardiovascular Research, Prague, Czechoslovakia
\end{abstract}

SYNOPSIS The therapeutic efficacy of a combination of gentamicin with carbenicillin was compared with those of each antibiotic alone. The efferent urinary ducts of rats were infected with Pseudomonas aeruginosa and antibiotic therapy was started six days later. After seven days' therapy quantitative bacteriological findings in the urine and renal tissue were compared with those of untreated rats that had been infected. The degree of infection was least in the group treated with concurrent gentamicin and carbenicillin. It was concluded that the therapeutic efficacy of the gentamicincarbenicillin combination exceeded those of each antibiotic administered alone.

Urinary tract infections due to Pseudomonas aeruginosa are very difficult to manage and may lead to complications including a potentially fatal bacteraemia (McCabe and Jackson, 1962; Melnick and Litvak, 1963). These infections occur mainly in urological wards and affect postoperative patients who undergo repeated catheterization of the urinary bladder or have functional and anatomical disturbances of the efferent urinary ducts. Interest in Pseudomonas infections has recently been increasing, especially in connexion with kidney transplantation, as the lowering of resistance by immunosuppressive agents plays a major role in the development of infections (Khastagir, Montandon, Nakamoto, and Kolff, 1969; Pletka, Cohen, Hulme, Kenyon, Owen, Thompson, Snell, Mowbray, Porter, Leigh, and Peart, 1969).

Until recently the only two antibiotics effective against Ps. aeruginosa were polymyxin B and colistin. Polymyxin B therapy, however, involves a risk of damage to the kidneys and to the central nervous system, while the efficacy of colistin in vivo is unsatisfactory. The discovery of two new antibiotics, gentamicin and carbenicillin, effective against strains of Ps. aeruginosa has therefore aroused much interest. But the clinical results with these antibiotics have not been as successful as anticipated on the basis of sensitivity tests in vitro.

Laboratory tests have indicated that synergism between gentamicin and carbenicillin exists (RolinReceived for publication 30 December 1970. son and Sutherland, 1967; Smith, Dans, Wilfert, and Finland, 1969), but no detailed report on the concurrent use of gentamicin and carbenicillin in Pseudomonas urinary tract infections has yet been published. We therefore carried out experiments in vivo in rats with an experimental model of cystitis, comparing under standard conditions the antibacterial effects of the gentamicin/carbenicillin combination with those of each drug administered alone.

The susceptibility of the strain Pseudomonas aeruginosa used in our experiments was investigated by a tube-dilution method. The strain was chosen at random and we cannot say whether it was one of the more susceptible or not. According to bactericidal concentrations of gentamicin and carbenicillin, this strain seems to be relatively susceptible.

\section{Materials and Methods}

A suspension was prepared of $P$ s. aeruginosa, strain no. $1908 / 69$, isolated from the urine of an inpatient in the urological ward. This was diluted with normal saline to give a concentration of about $2 \times 10^{8}$ cells $/ \mathrm{ml}$. Tube dilution tests on this strain indicated that the minimum inhibitory and bactericidal concentrations of gentamicin were 0.5 and $12.5 \mu \mathrm{g} / \mathrm{ml}$ and those of carbenicillin were 50 and $100 \mu \mathrm{g} / \mathrm{ml}$, respectively.

The experimental animals were albino, Wistar female rats each weighing $200 \pm 20 \mathrm{~g}$. While under 
general anaesthesia with pentobarbitone sodium, the anterior upper wall of the urinary bladder of each animal was incised approximately $2-3 \mathrm{~mm}$ and then sutured with three stitches. Immediately after suturing, $0.1 \mathrm{ml}$ of a freshly prepared suspension of $P s$. aeruginosa was injected through the wall into the bladder lumen using a thin needle. This procedure has been shown to result in a long-lasting chronic cystitis with high bacteriuria (Prát, Koníčková, Ritzerfeld, and Losse, 1969; Prát, Koníčková, and Hatala, 1969b and c).

Six days afterwards therapy was started with either carbenicillin, gentamicin, or one of two different combinations of both antibiotics. Duration of therapy was seven days. The first group of rats received carbenicillin intramuscularly at a dose of $330 \mathrm{mg} / \mathrm{kg}$ three times daily. The second group received gentamicin intramuscularly at a dose of $3 \mathrm{mg} / \mathrm{kg}$ three times daily. Another group received carbenicillin $330 \mathrm{mg} / \mathrm{kg}$ plus gentamicin $3 \mathrm{mg} / \mathrm{kg}$, intramuscularly, three times daily. The fourth group were given the combination intramuscularly at half this dosage, three times daily. Concurrently with the carbenicillin, probenecid $20 \mathrm{mg} / \mathrm{kg}$ three times daily was given by stomach tube. Probenecid inhibits the tubular secretion of carbenicillin thereby retarding renal elimination and prolonging high carbenicillin blood levels. During this seven-day period a control group of infected rats received $2 \mathrm{ml}$ distilled water three times daily by stomach tube. This corresponded to the volume of probenecid solution given and eliminated the potential influence on the urinary infection of enhanced diuresis.

The rats were killed by intraperitoneal injection of pentobarbitone sodium three to five days after the conclusion of therapy (the controls were killed on the first day and equal parts of each group were sacrificed on the second and third days). At necropsy the abdominal cavity was opened and urine withdrawn from the bladder via an injection needle. Both kidneys were then removed under sterile conditions, washed with sterile normal saline, and placed separately on Petri dishes. Both the urine and the homogenized renal tissues were examined bacteriologically. Serially diluted samples of urine and tissue homogenate were surface-innoculated onto Endo agar plates. The results were read after 18 hours' incubation at $37^{\circ} \mathrm{C}$ and the colony count was calculated per millilitre of urine or per gram of renal tissue.

The Wilcoxon non-parametric test was used to compare the Ps. aeruginosa content of the treated and untreated groups. The bacteriological findings were also expressed as point ratings as used in previous studies (Prát et al, 1969). In addition the body weight changes occurring during the experiment were evaluated.

\section{Results}

Necropsy showed connective adhesions between the urinary bladder and adjacent tissues, and the bladder wall was thickened at the site of the incision. In several instances residues of the suturing material were apparent. No calculi were found in the bladder and in all cases the kidneys had a normal gross appearance.

The quantitative bacteriological findings in the

\begin{tabular}{|c|c|c|c|c|c|c|c|c|c|}
\hline \multirow[t]{4}{*}{ Experimental Group } & \multirow{4}{*}{$\begin{array}{l}\text { No. } \\
\text { of } \\
\text { Rats }\end{array}$} & \multirow{4}{*}{$\begin{array}{l}\text { No. } \\
\text { of } \\
\text { Kidneys }\end{array}$} & \multicolumn{4}{|c|}{ No. of Bacteria (per $g$ or $m l$ ) } & \multirow{4}{*}{$\begin{array}{l}\text { Total } \\
\text { No. of } \\
\text { Points }\end{array}$} & \multirow{4}{*}{$\begin{array}{l}\text { Infection Index } \\
\text { (Total No. } \\
\text { of Points and } \\
\text { No. of Kidneys } \\
\text { or Animals) }\end{array}$} & \multirow{4}{*}{$\begin{array}{l}\text { Percentage } \\
\text { Evaluation } \\
\text { (Controls } \\
100 \% \text { ) }\end{array}$} \\
\hline & & & $0-10^{2}$ & $10^{3}-10^{4}$ & $10^{5}-10^{6}$ & $10^{7}$ & & & \\
\hline & & & \multicolumn{4}{|c|}{ Points Rating } & & & \\
\hline & & & 0 & 1 & 2 & $>3$ & & & \\
\hline \multicolumn{10}{|l|}{ Kidneys } \\
\hline I Controls & 10 & 19 & 1 & 13 & 4 & 1 & 22 & $1 \cdot 16$ & 100 \\
\hline II Carbenicillin & 10 & 20 & 1 & 18 & 1 & $\mathbf{0}$ & 20 & $1 \cdot 00$ & 86 \\
\hline III Gentamicin & 10 & 20 & 11 & 8 & 1 & $\mathbf{0}$ & 9 & 0.45 & 39 \\
\hline \multicolumn{10}{|l|}{ IV Carbenicillin + gentamicin } \\
\hline V Carbenicillin + gentamicin & 10 & 19 & 19 & 0 & $\mathbf{0}$ & 0 & 0 & 0 & 0 \\
\hline \multicolumn{10}{|l|}{ Urine } \\
\hline I & 10 & & $\mathbf{0}$ & 2 & 6 & 2 & 20 & $2 \cdot 0$ & 100 \\
\hline II & 10 & & 2 & 3 & 2 & 3 & 16 & $1 \cdot 6$ & 80 \\
\hline III & 10 & & 2 & 1 & 5 & 2 & 17 & $1 \cdot 7$ & 85 \\
\hline IV & 9 & & 3 & 1 & 5 & 0 & 11 & $1 \cdot 1$ & 55 \\
\hline V & 10 & & 2 & 4 & 4 & 0 & 12 & $1 \cdot 2$ & 60 \\
\hline
\end{tabular}

Table I Quantitative bacteriological findings in urine and kidneys

$$
\text { Statistical analysis Kidneys: } \left.\left.\begin{array}{l}
\text { I: III } \\
\text { I: IV } \\
\text { I: V }
\end{array}\right\} \mathbf{P}<0.01 \quad \text { Urine: } \begin{array}{l}
\text { I: IV } \\
\text { I: V V }
\end{array}\right\} \mathbf{P}<0.05
$$




\begin{tabular}{|c|c|c|c|c|c|c|c|c|c|}
\hline \multirow{3}{*}{$\begin{array}{l}\text { Mean values } \\
\text { Standard deviations } \\
\mathbf{P}\end{array}$} & $\begin{array}{l}\text { Untreated } \\
\text { Controls }\end{array}$ & \multicolumn{2}{|c|}{ Carbenicillin } & Gentamicin & \multicolumn{2}{|c|}{$\begin{array}{l}\text { Carbenicillin } \\
\text { (Low Dosage) }\end{array}$} & & \multicolumn{2}{|c|}{$\begin{array}{l}\text { Gentamicin } \\
\text { (High Dosage) }\end{array}$} \\
\hline & $\begin{array}{rr}213.0 & 209.0 \\
11.1 & 12.9\end{array}$ & $\begin{array}{r}215 \cdot 0 \\
15 \cdot 3\end{array}$ & $\begin{array}{r}212 \cdot 0 \\
18 \cdot 3\end{array}$ & $\begin{array}{rr}221.0 & 234.5 \\
15.4 & 11.9\end{array}$ & $\begin{array}{r}220 \cdot 0 \\
7 \cdot 8\end{array}$ & $\begin{array}{r}224 \cdot 5 \\
13 \cdot 0\end{array}$ & & $\begin{array}{r}212 \cdot 0 \\
18 \cdot 1\end{array}$ & $\begin{array}{r}210 \cdot 0 \\
17 \cdot 0\end{array}$ \\
\hline & $<0.05$ & & & $<0.001$ & & & & ns & \\
\hline
\end{tabular}

Table II Mean body weight $(g)$ before therapy and at necropsy in individual experimental groups

urine and kidneys, along with the point ratings, are given in Table I. In all 10 untreated control animals the microbial concentration in the urine was high, usually about $10^{6} / \mathrm{ml}$. In the rats treated with carbenicillin or gentamicin alone, the mean microbial concentrations in the urine were somewhat lower than in the controls but the differences were not statistically significant. Therapy with both antibiotics together, whether at low or high dosages, did not result in Pseudomonas-free urine, but on average the degree of infection was statistically lower than in control animals. The latter showed a lower degree of infection in the kidneys than in the urine. This was usually about $10^{4}$ cells per gram of tissue. After therapy with carbenicillin alone practically no differences compared with the controls were found whereas after gentamicin therapy the infection was lower by a statistically significant degree.

The most conspicuous effect was that of the combination of both antibiotics at the higher dosage. After therapy the renal tissue was bacteriologically negative in 15 out of 19 kidneys, with a very low microbial count in the remaining four kidneys. Lower doses of the combination also led to significantly better results than those obtained in the controls or in the groups receiving therapy with a single antibiotic. The number of positive findings, however, exceeded that obtained after combined therapy at the higher dosage.

A survey of mean body weights of the rats before therapy and at necropsy (Table II) showed that a significant body weight loss was registered only in the untreated controls. In the other experimental groups the changes were not significant, apart from an increase in body weight after gentamicin therapy.

\section{Discussion}

The reported synergism in vitro of gentamicin with carbenicillin against $P s$. aeruginosa does not necessarily guarantee clinical efficacy. This attempt to evaluate gentamicin/carbenicillin combinations in vivo in an experimental model of cystitis in rats was made for the following reasons:

1 Infections of the lower urinary tract by $P S$. aeruginosa occur mainly in patients with an underlying urological condition.
2 The major part of these antibiotics is excreted through the kidneys and attains high levels in the urine. Other authors (Kunin, 1969) have already stressed that a cystitis model is particularly suitable for the evaluation of antibacterial agents because an unequivocal appraisal of the results can be made from the bacteriological findings in the urine.

3 Drug tests in an animal model have the advantage over clinical tests that comparable groups can be assembled for the assessment of the drugs. This is impossible in clinical practice because of individual differences in the character of urinary tract disease.

In a Pseudomonas urinary tract infection the kidneys are infected to a greater degree than has previously been found in the analogous $E$. coli cystitis model (Prát et al, 1969). Even so, the presence of pyelonephritis was unlikely because at necropsy the kidneys always showed a normal gross appearance. Since histological examinations of the kidneys were not made, however, the presence of microscopic or inflammatory changes cannot be eliminated.

The results under our experimental conditions are in agreement with the sensitivity tests in vitro. They confirm the synergy obtained with a combination of gentamicin and carbenicillin which resulted in an extinction, or at least a restriction, of the renal infection. In the urine a reduction in the degree of infection was also apparent, but infection was only occasionally completely eliminated. The most likely explanation of these differences is that the renal infection was of a lower severity than the bacteriuria. The suture, and also the lesion of the bladder wall due to cicatrix, may have played some part in causing the lower response of the bladder infection. Presumably this site is the principal focus of infection in which the microbes propagate and from where they infect the urine and possibly penetrate the kidneys by reflux.

\section{References}

Khastagir, B., Montandon, A. , Nakamoto, S., and Kolff, W. J. (1969). Early and late failures of human cadaveric renal allografts. Arch. intern. Med., 123, 8-14.

Kunin, C. M. (1969). Correlation between urinary bacteriology, bacterial infection and sensitivity to treatment. In IVth International Congress on Nephrology, Stockholm, 1969, Abstr. 182 
McCabe, W. R., and Jackson, G. G. (1962). Gram-negative bacteremia. I. Etiology and ecology. Arch. intern. Med., 110, 847-855.

Melnick, I., and Litvak, A. S. (1963). Gram-negative bacteremia: an evaluation of fifty-nine cases during 1963. J. Urol.,96, 257-262.

Pletka, P., Cohen, S. L., Hulme, B., Kenyon, J. R., Owen, K., Thompson, A. E., Snell, M., Mowbray, J. F., Porter, K. A., Leigh, D. A., and Peart, W. S. (1969). Cadaveric renal transplantation. An analysis of 65 cases. Lancet, 1, 1-6.

Prát, V., Konícková, L., Ritzerfeld, W., and Losse, H. (1969). Carbenicillin und Gentamycin bei der experimentellen Pseudomonas-Zystitis. Int. J. clin. Pharmacol., 3, 213-216.

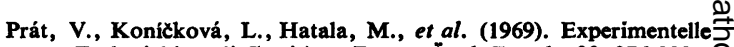
Escherichia coli-Cystitis er Ratte. Arztl. Forsch., 23, 376-380. 으

Prát, V., Konícková, L., and Hatala, M. (1969). The influence of water diuresis on the course of experimental E. coli bacteriuria in rats. Acta biol. med. germ., 26, 781-787.

Rolinson, G. N., and Sutherland, R. (1967). Carbenicillin, a new semisynthetic penicillin active against Pseudomonas aeruginosa. Antimicrob. Agents Chemother., 7, 609-613.

Smith, C. B., Dans, P. E., Wilfert, J. N., and Finland, M. (1969). Use of gentamicin in combinations with other antibiotics. J. infect. Dis., 119, 370-377.
है 